\title{
KEDUDUKAN HUKUM AKTA PEMBERIAN HAK TANGGUNGAN YANG TERLAMBAT DIDAFTARKAN
}

\author{
Agus Wiyono \\ Magister Kenotariatan, Fakultas Hukum, Universitas Narotama Surabaya \\ Email: aguswiyonoyono46@gmail.com
}

\begin{abstract}
ABSTRAK
Undang-Undang Hak Tanggungan menentukan bahwa tanggal Buku Tanah Hak Tanggungan adalah tanggal hari ketujuh setelah penerimaan. Hal tersebut menimbulkan permasalahan apabila Akta Pemberian Hak Tanggungan (APHT) sudah selesai ditandatangani. Penelitian ini menganalisis kedudukan hukum akta pemberian hak tanggungan yang pendaftarannya terlambat di Kantor pertanahan dan perlindungan hukum bagi debitur dan kreditur atas akta pemberian hak tanggungan yang terlambat pendaftarannya di Kantor pertanahan yang menimbulkan kerugian bagi para pihak. Metode penelitian yang digunakan adalah penelitian hukum normatif sedangkan pendekatan masalah dilakukan dengan menggunakan pendekatan undang-undang dan pendekatan konseptual. Hasil penelitian menunjukkan bahwa kedudukan hukum Akta pemberian Hak Tanggungan yang terlambat didaftarkan ke Kantor Pertanahan adalah tetap sah karena telah memenuhi ketentuan Pasal 13 UUHT. Perlindungan hukum bagi dabitur dan kreditur atas APHT yang terlambat didaftarkan ke Kantor Pertanahan terdapat pada Pasal 23 ayat (2) UUHT yang mengatur bahwa dengan adanya sanksi administrasi tidak menghapus sanksi lain sesuai peraturan perundang-undangan yang berlaku sehingga pihak yang dirugikan dapat mengajukan gugatan ganti rugi.
\end{abstract}

Kata Kunci: Hak Tanggungan, Akta Pemberian Hak Tanggungan, Perlindungan Hukum

\begin{abstract}
The Underwriting Rights Law stipulates that the date of the book of land liability is the seventh day after receipt. It raises problems if the Deed of Granting the Right of Entitlement (APHT) has been completed. This study analyzes the legal standing of the deed of giving rights of late registration at the Land Office and legal protection for debtors and creditors on deeds granting mortgage rights that are late in registering at the Land Office which cause losses to the parties. The research method used normative legal research while the problem approach was carried out using a legal approach and conceptual approach. The results of the study indicate that the legal position of the Deed of Granting Rights that is late registered with the Land Office is still valid because it has fulfilled the provisions of Article 13 UUHT. Legal protection for dabitur and creditor over the APHT that is late registered with the Land Office is found in Article 23 paragraph (2) UUHT which stipulates that the existence of administrative sanctions does not remove other sanctions in accordance with prevailing laws and regulations so that the aggrieved party can file compensation.
\end{abstract}

Key words: Mortgage Rights, Deed of Giving Rights, Legal Protection 


\section{PENDAHULUAN}

Untuk mendorong dan menggairahkan dunia usaha, pemerintah memberi dukungan dengan menyediakan berbagai fasilitas dan bermacam-macam sarana termasuk didalamnya upaya dalam menunjang permodalan dengan menyediakan fasilitas kredit. Salah satu alternatif dalam pendanaan yang dapat digunakan adalah melalui bank. Kedudukan bank sebagai lembaga keuangan yang kegiatan operasionalnya berada dalam lingkup usaha menghimpun dana dari masyarakat dan mengelola dana tersebut dengan menanamnya kembali kepada masyarakat (dalam bentuk pemberian kredit) sampai dan tersebut kembali lagi ke bank. ${ }^{1}$ Untuk itu dalam setiap kegiatan perkreditan, pihak bank perlu memperoleh jaminan atas pembayaran piutangnya, yaitu dengan cara meminta benda jaminan kepada nasabah atau debitor.

Secara garis besar dikenal ada dua bentuk jaminan, yaitu jaminan perorangan dan jaminan kebendaan. Dalam praktek jaminan yang paling sering digunakan adalah jaminan kebendaan yang salah satunya adalah tanah yang dijadikan jaminan atau disebut dengan Hak Tanggungan. Dalam Pasal 51 UUPA, telah diatur suatu lembaga jaminan untuk hak atas tanah yang disebut dengan Hak Tanggungan, berkaitan dengan hal tersebut, maka lahirlah Undang-Undang Nomor 4 Tahun 1996 tentang Hak Tanggungan Atas Tanah Serta Benda-Benda Yang Berkaitan Dengan Tanah (UUHT). ${ }^{2}$

Sejak diberlakukannya UUHT, terjadi perubahan besar terhadap sistem dan metode penjaminan atas suatu hutang. Sebelum berlakunya UUHT tersebut, dengan berdasarkan pada Kitab Undang-Undang Hukum Perdata Barat, Bank yang memberikan fasilitas kredit hanyalah memberikan kewajiban kepada nasabah/debiturnya untuk menanda-tangani akta Surat Kuasa Memasang Hipotik

\footnotetext{
${ }^{1}$ Hasannudin Rahman, Aspek-aspek Pemberian Kredit Perbankan di Indonesia, Citra Aditya Bakti, Bandung, 1995, hal. 9

${ }^{2}$ Eugema Liliawati Mulyono, Tinjauan Yuridis Undang-undang Nomor 4 Tahun 1996 tentang Hak Tanggungan Dalam Kaitannya Dengan Pemberian Kredit Oleh Perbankan, Harvarindo, Jakarta, 2009, hal. 1
} 
yang dibuat secara Notariil, untuk menjamin pelunasan hutang dan/atau kewajiban dari debitur tersebut.

Setelah diberlakukannya UUHT tersebut, maka setiap debitur yang menjaminkan tanah dan/atau bangunannya kepada kreditur (baik bank maupun bukan bank) untuk menjamin pelunasan fasilitas kredit yang diterimanya, maka diwajibkan untuk menanda-tangani akta Surat Kuasa Membebankan Hak Tanggungan (SKMHT) atau akta Pemberian Hak Tanggungan (APHT), yang akan dilanjutkan dengan pendaftaran Hak Tanggungannya pada Kantor Pertanahan dimana tanah tersebut di daftarkan.

Pada tahap pemberian Hak Tanggungan dengan Akta PPAT oleh pemberi Hak Tanggungan kepada kreditor, Hak Tanggungan yang bersangkutan belum lahir, Hak Tanggungan tersebut baru lahir pada saat dibuatnya buku tanah Hak Tanggungan oleh Kantor Pertanahan. Oleh karena itu, saat didaftarnya Hak Tanggungan tersebut merupakan hal yang sangat penting bagi kreditor, dan merupakan momen yang sangat penting sehubungan dengan munculnya hak tagih preferen dari kreditor, menentukan tingkat atau kedudukan kreditor terhadap sesama kreditor dalam hal ada sita jaminan (conservatoir beslag) atas benda jaminan. ${ }^{3}$ Dengan perkataan lain bahwa kreditor yang lebih dahulu APHT-nya didaftar dalam Buku Tanah Hak Tanggungan oleh Kantor Pertanahan dialah (kreditor) yang harus lebih dahulu diutamakan dari kreditor lainnya.

Menurut Pasal 13 UUHT, pemberian Hak Tanggungan wajib didaftarkan pada Kantor Pertanahan, dimana merupakan syarat mutlak untuk lahirnya Hak Tanggungan dan mengikatkan Hak Tanggungan terhadap pihak ketiga dan di dalam Akta Pemberian Hak Tanggungan (APHT) wajib dicantumkan secara lengkap, baik mengenai subyek, obyek, termasuk utang yang dijamin dengan Hak Tanggungan, serta kewajiban untuk mendaftarkan pemberian Hak Tanggungan tersebut pada Kantor Pertanahan setempat. Pendaftaran ini dimaksudkan sebagai suatu

${ }^{3}$ J. Satrio, Hukum Jaminan : Hak Jaminan. Hak Tanggungan, Citra Aditya Bakti, Bandung. 1998, hal. 38 
pengumuman yang bersifat ke dalam yaitu menyangkut para pihak, maupun terhadap masyarakat luas.

Pasal 13 ayat (2) dan (3) UUHT juga menentukan tata cara pendaftaran Hak Tanggungan itu dilakukan. Pendaftaran Hak Tanggungan dilakukan oleh Kantor Pertanahan dengan cara membuat Buku Tanah Hak Tanggungan dan selanjutnya mencatat Hak Tanggungan yang bersangkutan dalam Buku Tanah Hak Atas Tanah yang bersangkutan yang ada di Kantor Pertanahan, selanjutnya menyalin catatan tersebut dalam sertifikat Hak Atas Tanah yang bersangkutan.

Setelah APHT dan Warkah yang diperlukan diterima oleh Kantor Pertanahan dan dibuatkan Buku Tanah Hak Tanggungan maka buku tersebut harus diberi tanggal. Tanggal Buku Tanah Hak Tanggungan mempunyai peranan yang sangat penting, karena ia mempunyai pengaruh yang menentukan atas kedudukan kreditor pemegang Hak Tanggungan terhadap sesama kreditor yang lain terhadap debitor yang sama (Pasal 1132 dan Pasal 1133 KUH-Perdata). Dengan lahirnya Hak Tanggungan maka kreditor Hak Tanggungan yang bersangkutan berkedudukan sebagai kreditor preferen terhadap para kreditor konkuren ( Pasal 1 UUHT ). ${ }^{4}$

Menurut ketentuan Pasal 13 ayat (4) UUHT ternyata tanggal Buku Tanah Hak Tanggungan adalah tanggal hari ketujuh setelah penerimaan secara lengkap suratsurat yang diperlukan bagi pendaftarannya dan jika hari ketujuh jatuh pada hari libur tanggal buku tanah yang bersangkutan diberi tanggal hari kerja berikutnya. Menurut Pasal 14 ayat (1) UUHT sebagai tanda bukti adanya Hak Tanggungan Kantor Pertanahan menerbitkan sertifikat Hak Tanggungan yang terdiri dari salinan Buku Tanah Hak Tanggungan dan salinan APHT bersangkutan yang sudah disahkan oleh Kepala Kantor Pertanahan.

Sesuai ketentuan Pasal 14 ayat (4) UUHT, Pada dasarnya sertifikat Hak Atas Tanah yang sudah dibubuhi catatan pembebanan Hak Tanggungan ini diserahkan kembali kepada pemegang Hak Atas Tanah (pemberi Hak Tanggungan), namun biasanya sudah diperjanjikan bahwa sertifikat hak atas tanah tersebut disimpan oleh

${ }^{4}$ Ibid. hal. 144 
pemegang Hak Tanggungan dalam rangka melaksanakan hak-hak istimewa yang dimilikinya.

Jika diperhatikan dalam Pasal 13 ayat (4) UUHT tidak dikatakan "paling lambat", akan tetapi "hari ketujuh" . Jadi meskipun surat-surat sudah diterima dengan lengkap oleh Kantor Pertanahan dan petugasnya mempunyai kesempatan untuk segera mendaftarkan, tetapi sesuai dengan kata-kata Pasal 13 ayat (4) UUHT, tanggal pendaftaran yang menentukan tanggal lahirnya Hak Tanggungan, tetap saja tidak bisa lebih maju daripada hari ketujuh. Bahkan menurut Pasal 23 ayat (4) UUHT Pejabat Kantor Pertanahan apabila melanggar ketentuan Pasal 13 ayat (4), yaitu membuat tanggal buku tanah Hak Tanggungan melewati hari ketujuh dapat dikenai sanksi administrasi.

Karena yang menentukan lahirnya Hak Tanggungan yang diperjanjikan para pihak dalam APHT adalah Pejabat Kantor Pertanahan yang nota bene adalah bukan pihak dalam APHT. Maka timbul pertanyaan apabila APHT sudah selesai ditandatangani, namun ada beberapa persyaratan surat yang ada belum dilengkapi dan pendaftaran melebihi batas hari ketujuh kemudian masuk pemberitahuan dan permohonan sita jaminan, bagaimana nasib pemberian Hak Tanggungan yang bersangkutan. Untuk melindungi kepentingan para pihak dan mencegah berlarutlarut pemberian tanggal Buku Tanah Hak Tanggungan, mestinya ditentukan berapa hari paling lambat harus dibuat Buku Tanah Hak, Tanggungan bukan dengan menentukannya sekian hari sesudah berkas diterima, yaitu hari ketujuh.

\section{RUMUSAN MASALAH}

1. Apa kedudukan hukum akta pemberian hak tanggungan yang pendaftarannya terlambat di Kantor pertanahan?

2. Apa perlindungan hukum bagi debitur dan kreditur atas akta pemberian hak tanggungan yang terlambat pendaftarannya di Kantor pertanahan yang menimbulkan kerugian bagi para pihak?

\section{METODE PENELITIAN}


Penelitian ini menggunakan metode penelitian hukum normatif yang dilakukan untuk mencari pemecahan masalah atas permasalahan hukum yang ada. Pendekatan penelitian yang digunakan adalah pendekatan undang-undang (statute approach) dan pendekatan konseptual (conceptual approach).

\section{PEMBAHASAN}

\section{Kedudukan Hukum Akta Pemberian Hak Tanggungan Yang Terlambat Didaftarkan Pada Kantor Pertanahan}

Pasal 1 angka 1 UUHT memberikan definisi Hak Tanggungan sebagai berikut:

Hak Tanggungan adalah hak jaminan yang dibebankan pada hak atas tanah sebagaimana dimaksud dalam Undang-Undang Nomor 5 Tahun 1960 tentang Peraturan Dasar Pokok-Pokok Agraria, berikut atau tidak berikut bendabenda lain yang merupakan satu kesatuan dengan tanah itu, untuk pelunasan hutang tertentu yang memberikan kedudukan yang diutamakan kepada kreditor tertentu terhadap kreditor-kreditor lain.

Ada bebebarapa unsur pokok dari hak tanggungan yang termuat di dalam definisi tersebut, yaitu:

1) Hak Tanggungan adalah hak jaminan untuk pelunasan hutang.

2) Objek Hak Tanggungan adalah hak atas tanah sesuai UUPA.

3) Hak Tanggungan dapat dibebankan atas tanahnya (hak atas tanah) saja, tetapi dapat pula dibebankan berikut benda-benda lain yang merupakan satu kesatuan dengan tanah itu.

4) Hutang yang dijamin harus suatu utang tertentu.

5) Memberikan kedudukan yang diutamakan kepada kreditur tertentu terhadap kreditur-kreditur lain. ${ }^{5}$

Hak tanggungan tidak dapat berdiri sendiri tanpa didukung oleh suatu perjanjian (perjanjian kredit) antara debitur dan kreditur. Oleh karenanya hak tanggungan dikatakan accessoir (mengikuti) perjanjian pokoknya. Kredit yang

${ }^{5}$ Hatta Isnaini Wahyu Utomo, "Hukum Jaminan”, Bahan Ajar Mata Kuliah Hukum Jaminan, Universitas Yos Sudarso, 2017, hal. 6 
diberikan oleh kreditur mengandung resiko, maka dalam setiap pemberian kredit, bank tidak diperkenankan memberikan kredit tanpa ada suatu perjanjian tertulis. Itu sebabnya diperlukan suatu jaminan kredit dengan disertai keyakinan akan kemampuan debitur melunasi utangnya. Hal ini sesuai dengan ketentuan Pasal 8 Undang-Undang Nomor 7 Tahun 1992 Tentang Perbankan yang menyatakan dalam memberikan kredit, bank umum wajib mempunyai keyakinan atas kemampuan dan kesanggupan debitur untuk melunasi hutangnya sesuai yang diperjanjikan. Yang dapat dibebankan dengan Hak Tanggungan adalah tanah Hak Milik, tanah Hak Guna Bangunan dan/atau tanah Hak Guna Usaha.

UUHT memberikan kedudukan Kreditor tertentu yang kuat dengan ciri-ciri sebagai berikut: ${ }^{6}$

1) Membuat kedudukan seorang kreditor menjadi diutamakan dibandingkan kreditornya ("droit de preference");

2) Hak Tanggungan mengikuti obyek yang dijaminkan di tangan siapapun obyek itu berada atau selama perjanjian pokok belum dilunasi (“droit de suite");

3) Dapat mengikat pihak ketiga dan memberikan kepastian hukum pada pihak-pihak yang berkepentingan ketika memenuhi asas spesialitas dan asas publisitas;

4) Mudah dan pasti pelaksanaan eksekusinya.

Pembebanan Hak Tanggungan terdiri dari dua tahap, yaitu Pemberian Hak Tanggungan dan Pendaftaran Hak Tanggungan. Tata cara pembebanannya wajib memenuhi syarat yang ditetapkan dalam Pasal 10 ayat (1); Pasal 11 ayat (1); Pasal 12; Pasal 13 dan Pasal 14 UUHT.

Syarat sahnya pembebanan Hak Tanggungan yaitu Pemberian Hak Tanggungan dilakukan dengan pembuatan APHT oleh PPAT sesuai dengan Pasal 10 ayat (2) UUHT. Pemberian Hak Tanggungan wajib memenuhi syarat spesialitas (Pasal 11 ayat (1) UUHT) yang meliputi : Nama dan identitas pemegang dan pemberi hak tanggungan, Domisili para pihak, pemegang dan pemberi hak tanggungan, Penunjukkan secara jelas hutang atau hutang-hutang yang dijamin pelunasannya

${ }^{6}$ Advendi. S \& Elsi Kartika.S, Hukum dan Ekonomis Edisi II, Grasindo, Jakarta, 2007, hal. 21 
dengan hak tanggungan, Nilai Tanggungan, Uraian yang jelas mengenai objek hak tanggungan.

Pemberian Hak Tanggungan dihadapan PPAT baru dipenuhi syarat spesialitas. Maka Hak Tanggungan yang bersangkutan belum lahir, kreditor belum memperoleh kedudukan istimewa. Bagi kelahirannya masih harus dipenuhi syarat publisitas, yaitu pendaftarannya oleh Kepala Kantor Pertanahan.

Jadi setelah PPAT selesai membuat Akta Pemberian Hak Tanggungan, selanjutnya PPAT mengirim berkas dan kelengkapannya tersebut ke Kantor Pertanahan untuk didaftar. Pemberian Hak Tanggungan sebagaimana diatur dalam ketentuan Pasal 13 ayat (2) UUHT

Kewajiban pendaftaran Hak Tanggungan dapat ditemukan rumusannya dalam Pasal 13 UUHT, yang menyatakan sebagai berikut:

a. Pemberian Hak Tanggungan wajib didaftarkan pada Kantor Pertanahan selambatlambatnya 7 (tujuh) hari kerja setelah penandatanganan Akta Pemberian Hak Tanggungan (APHT).

b. Pendaftaran Hak Tanggungan dilakukan oleh Kantor Pertanahan dengan membuatkan buku tanah Hak Tanggungan dan mencatatnya dalam buku tanah atas tanah yang menjadi objek Hak Tanggungan serta menyalin catatan resebut pada sertifikat hak atas tanah yang bersangkutan.

c. Tanggal buku tanah Hak Tanggungan adalah hari ketujuh setelah penerimaan secara lengkap surat-surat yang diperlukan bagi pendaftarannya dan jika hari ketujuh itu jatuh pada hari libur, buku tanah yang bersangkutan diberi tanggal hari kerja berikutnya.

d. Hak tanggungan lahir pada hari tanggal buku tanah Hak Tanggungan.

Dari rumusan Pasal 13 UUHT dapat diketahui bahwa Hak Tanggungan lahir pada saat pendaftaran Hak Tanggungan pada buku Tanah hak atas tanah yang dibebankan dengan hak tanah (sesuai tanggal yang diberikan). Sebagai bukti adanya hak tanggungan, Kantor Pertanahan menerbitkan sertifikat hak tanggungan.

UUHT memberi batasan pendaftaran Hak Tanggungan yaitu selama 7 hari setelah penandatangan APHT. Setelah didaftarkan maka akan keluar Sertifikat Hak 
Tanggungan. Namun pada kenyataannya sering kali pendaftaran Hak Tanggungan dilakukan melebihi waktu yang ditentukan, yaitu melewati jangka waktu 7 hari yang ditentukan undang - undang. Pendaftaran Hak Tanggung kepada Kantor Pertanahan merupakan saat lahirnya suatu hak tanggungan dan merupakan salah satu asas dari Hak Tanggungan. Dengan tidak didaftarkan hak tanggungan atau pendaftarannya tidak memenuhi unsur-unsur yang terdapat pada Pasal 13 UUHT, maka perjanjian yang dibuat para pihak tetaplah berlaku. Namun tidak memenuhi unsur dari hak tanggungan. Sehingga kreditur dari hak tanggungan tidak memiliki hak sebagai kreditur preferen sebagaimana kreditur hak tanggungan.

\section{Perlindungan Hukum Bagi Debitur Dan Kreditur Atas Akta Pemberian Hak Tanggungan Yang Terlambat Pendaftarannya Di Kantor Pertanahan}

Perlindungan hukum dalam arti sempit adalah sesuatu yang diberikan kepada subjek hukum dalam bentuk perangkat hukum, baik yang bersifat preventif maupun represif, serta dalam bentuk yang tertulis maupun tidak tertulis. Dengan kata lain, perlindungan hukum dapat diartikan sebagai suatu gambaran dari fungsi hukum, yaitu ketenteraman bagi segala kepentingan manusia yang ada di dalam masyarakat sehingga tercipta keselarasan dan keseimbangan hidup masyarakat. Sedangkan perlindungan hukum dalam arti luas adalah tidak hanya diberikan kepada seluruh makhluk hidup maupun segala ciptaan Tuhan dan dimanfaatkan bersama-sama dalam rangka kehidupan yang adil dan damai.

Sebagaimana diketahui, bahwa tujuan dari adanya lembaga jaminan adalah untuk memberikan perlindungan, khususnya kepada kreditor apabila debitor wanprestasi. Untuk memberikan perlindungan kepada kreditor dirasa tidak cukup hanya dengan dibuatkan APHT saja, tetapi juga harus diikuti dengan pendaftarannya ke Kantor Pertanahan mengenai adanya Hak Tanggungan tersebut. Karena Hak Tanggungan baru lahir dan yang akan menjadikan kedudukan kreditor menjadi kreditor preferen daripada kerditor-kreditor yang lain, yaitu pada saat dibuatnya buku tanah Hak Tanggungan yang bersangkutan. Maka setelah penandatanganan APHT 
oleh para pihak, PPAT yang membuat akta tersebut harus mengirim berkasnya ke Kantor Pertanahan guna didaftar adanya beban Hak Tanggungan tersebut.

Berdasarkan Penjelasan Pasal 10 UUHT, dijelaskan bahwa perjanjian yang menimbulkan hubungan utang-piutang yang dijamin pelunasannya dapat dibuat dalam 2 (dua) bentuk, yaitu baik berupa akta dibawah tangan maupun akta autentik, tergantung pada ketentuan hukum yang mengatur materi perjanjian itu. Bentuk perlindungan hukum yang diberikan kepada pihak debitor menurut ketentuan dalam Undang-Undang Hak Tanggungan ini terdapat dalam bentuk perjanjian kredit itu sendiri. Perjanjian kredit ini berfungsi sebagai alat bukti serta memberikan batasan mengenai hak dan kewajiban masing-masing pihak. ${ }^{7}$

Bentuk perlindungan hukum yang diberikan kepada kreditor ketika debitor wanprestasi terdapat dalam bentuk perjanjian kredit, dimana berdasarkan Penjelasan Pasal 10 UUHT dijelaskan bahwa Perjanjian yang menimbulkan hubungan utangpiutang dapat dibuat dengan akta di bawah tangan maupun akta autentik tergantung pada ketentuan hukum yang mengatur materi.

Dalam hal akta Hak Tanggungan tidak didaftarkan dikantor pertanahan akan menimbulkan akibat hukum, yaitu Sertifikat Hak Tanggungan tidak dapat diterbitkan. Jika Sertifikat Hak Tanggungan tidak diterbitkan, maka tidak pernah lahir hak tanggungan, sehingga kreditor akan mengalami kesulitan untuk mengeksekusi, apabila Debitor wanprestasi atau cidera janji, karena dalam UUHT telah dijelaskan bahwa apabila Debitor wanprestasi maka benda yang menjadi objek hak tanggungan dapat dieksekusi dengan cara pelaksanaan title eksekutorial, penjualan benda yang menjadi objek hak tanggungan dan penjualan dibawah tangan.

Untuk memberikan kepastian hukum, Pasal 13 UUHT mewajibkan Hak Tanggungan didaftarkan di BPN. Pendaftaran memiliki arti yuridis sebagai suatu rangkaian yang tidak terpisah dari proses terjadinya perjanjian Hak Tanggungan. Selain itu Pendaftaran merupakan perwujudan dari azas publisitas dan kepastian hukum. Hak kebendaan dari Hak Tanggungan baru lahir sejak dilakukannya

${ }^{7}$ H.R. Daeng Naja, Hukum Kredit dan Bank Garansi, The Bankers Hand Book, Citra Aditya Bakti, Bandung, 2005, hal. 183 
pendaftaran pada BPN dan sebagai buktinya adalah diterbitkannya Sertifikat Hak Tanggungan.

Oleh karenanya guna meminimalisir tidak terlindunginya secara hukum baik Kreditur maupun Debitur terkait dengan pembuatan Perjanjian Kredit, pengakuan Hutang, dan pemasangan APHT, Notaris PPAT harus melaksanakan tugas dengan sebaik-baiknya sesuai dengan fungsi dan tugasnya selaku pejabat Umum, terutama saat membuat (redaksi) akta perjanjian Kredit (PK), Pengakuan hutang (PH), diusahakan yang seimbang terkait dengan hak dan kewajiban baik Kreditur (Bank) maupun Debitur. Karena dalam praktek, masing-masing Bank telah memilikl form Perjanjian Kredit $(\mathrm{PK})$ dan pengakuan Hutang $(\mathrm{PH})$ sendiri-sendiri dimana Notaris diminta membuat sesuai/sama dengan form yang dikehendaki Bank tersebut, bahkan ada beberapa Bank yang telah mencetak perjanjian standard, dimana Notaris hanya diminta melegalisir perjanjian standard tersebut, yang otomatis sangat memprotek pihak Bank dan merugikan/mengurangi hak Debitur).

\section{PENUTUP}

\section{Kesimpulan}

Kedudukan hukum Akta pemberian Hak Tanggungan yang terlambat didaftarkan ke Kantor Pertanahan adalah tetap sah karena telah memenuhi ketentuan Pasal 13 UUHT. Perlindungan hukum bagi dabitur dan kreditur atas APHT yang terlambat didaftarkan ke Kantor Pertanahan terdapat pada Pasal 23 ayat (2) UUHT yang mengatur bahwa dengan adanya sanksi administrasi tidak menghapus sanksi lain sesuai peraturan perundang-undangan yang berlaku, ini akan memberikan ruang bagi para pihak baik kreditur maupun debitur untuk melakukan tuntutan ganti apabila ada peristiwa hukum karena hubungan hukum lain yang mengakibatkan dilaksanakannya suatu gugatan ataupun dilaksanakannya suatu eksekusi oleh pihak lain pada obyek yang sama.

\section{Saran}


Pejabat Pembuat Akta Tanah wajib memahami ketentuan pendaftaran Akta Pemberian Hak Tanggungan agar tidak merugikan kepentingan para pihak yang membuat akta dihadapannya. Pemahaman akan ketentuan pendaftaran hak tanggungan dapat membuat PPAT terhindar dari gugatan para pihak yang dirugikan akibat tidak terpenuhinya asas publisitas dalam Hak Tanggungan.

\section{DAFTAR PUSTAKA}

Advendi. S \& Elsi Kartika.S, Hukum dan Ekonomis Edisi II, Grasindo, Jakarta, 2007

Eugema Liliawati Mulyono, Tinjauan Yuridis Undang-undang Nomor 4 Tahun 1996 tentang Hak Tanggungan Dalam Kaitannya Dengan Pemberian Kredit Oleh Perbankan, Harvarindo, Jakarta, 2009

H.R. Daeng Naja, Hukum Kredit dan Bank Garansi, The Bankers Hand Book. Citra Aditya Bakti, Bandung, 2005

Hasannudin Rahman, Aspek-aspek Pemberian Kredit Perbankan di Indonesia, Citra Aditya Bakti, Bandung, 1995

Hatta Isnaini Wahyu Utomo, "Hukum Jaminan”, Bahan Ajar Mata Kuliah Hukum Jaminan, Universitas Yos Sudarso, 2017

J. Satrio, Hukum Jaminan : Hak Jaminan. Hak Tanggungan, Citra Aditya Bakti, Bandung. 1998 